\title{
Income Distribution and Human Trafficking Outflows
}

\author{
Cassandra E. DiRienzo ${ }^{1} \&$ Jayoti $_{\text {Das }}^{2}$ \\ ${ }^{1}$ Love School of Business, Elon University, Elon, North Carolina, USA \\ ${ }^{2}$ Love School of Business, Elon University, Elon, North Carolina, USA \\ Correspondence: Cassandra DiRienzo, Love School of Business, Elon, North Carolina, USA.
}

Received: February 7, 2018 Accepted: February 27, 2018 Online Published: March 9, 2018

doi:10.5539/res.v10n2p28

URL: https://doi.org/10.5539/res.v10n2p28

\begin{abstract}
This study seeks to close the gap between the theoretical rationale for the role of income inequality in human trafficking and lack of empirical evidence supporting this relationship. It is argued that differences in income, especially the income of the poorest in the population, is a significant push factor encouraging individuals to undertake risky migration. Nonetheless, the Gini coefficient, which is typically used in human trafficking research, does not accurately capture the theoretical rationale for why difference in population income, especially the income of the poorest in the population, should matter. A different metric for measuring income inequality - one that is tied to the theoretical underpinnings -- is introduced. Empirical evidence supporting the role that income plays on the poorest in the population on human trafficking outflows is offered. Specifically, as the poorest in the population become marginally better off, there is an increase in human trafficking outflows at the country level.
\end{abstract}

Keywords: human trafficking, income inequality, push factors, human trafficking outflows

\section{Introduction}

Human trafficking is a heinous crime in which men, women, and children are purchased like commodities and forced into such atrocities as prostitution, organized begging, domestic servitude, pornography, bonded or forced labor, and other gross assaults on their civil and personal freedoms such as organ harvesting (Agbu, 2003; Studnicka, 2010; U.S. Department of State). Traffickers typically prey on vulnerable populations such as children, young women, single mothers and the impoverished. The crime tends to initiate when these vulnerable individuals seek work and an improved economic status and, through a variety of deceptive ploys, traffickers promise these individuals respectable work and a better life elsewhere. Once ensnared and relocated, traffickers confiscate their identification and the victims come to the sad realization that they have been tricked into miserable conditions (Adepoju, 2005; Gajic-Veljanoski \& Stewart, 2007). Often facing language barriers and without identification, an understanding of the crime, or their legal rights (if any), victims are dependent on their traffickers or to the person(s) to whom they were sold. Considering victims originate from vulnerable populations, when they are placed in even direr situations these individuals can be easily controlled through violence, coercion and threats (Sigmon, 2008; Bales, Trodd, \& Williamson, 2009).

Despite the dreadful nature of the crime, human trafficking is growing at an alarming rate and, in the next ten years, it is predicted to surpass both drug and arms trafficking to become the largest form of criminal activity in incidence (Dijk and Mierlo, 2014; United Nations; Winterdyk \& Reichel, 2010; Wheaton et al., 2010). The current prevalence rates are staggering as the United Nations Office on Drugs and Crime (UNODC) conservatively estimates that an one time there are 2.5 million people living as human trafficking victims (Potrafke, 2013). The growth of the crime and the incident rates can be explained, at least in part, by the profitability of the crime. The UNODC reports that human trafficking generates as much as 36 billion dollars in annual profit for criminals and the United Nations classifies human trafficking as the world's third most profitable crime (Potrafke, 2013; Winterdyk \& Reichel, 2010; Fichtelberg, 2008).

In a special event held at the headquarters of the United Nations in July 2014, the president of the General Assembly stated that human trafficking has 'no place in the modern world'. At this same event the president of the Economic and Social Council stated that a better understanding of the crime is needed; in short, in order to fight the crime, greater knowledge of the driving and facilitating factors is needed. To this end, the focus of this study is to further explore the role of income inequality and poverty as driving factors in human trafficking. While past research has made strong arguments for the relevance of income distribution as a trafficking determinant, this relationship has largely not been established empirically. It is argued here that differences in population incomes do matter, but not in the way it has been described and measured in previous research regarding human trafficking. Specifically, the Gini coefficient, which is typically used in 
human trafficking research, does not accurately capture the theoretical rationale for why differences in income, especially the income of the poorest in the population, should be a significant driver of human trafficking. A background on human trafficking research and a theoretical justification for the hypotheses follows.

\section{Human Trafficking Outflows and Income Inequality}

\subsection{Overview of Human Trafficking}

In the United Nations Protocol to Prevent, Suppress and Punish Trafficking in Persons, especially Women and Children (2000), human trafficking is defined as, "the recruitment, transportation, transfer, harbouring or receipt of persons, by means of the threat or use of force or other forms of coercion, of abduction, of fraud, of deception, of the abuse of power or of a position of vulnerability or of the giving or receiving of payments or benefits to achieve the consent of a person having control over another person, for the purpose of exploitation." More broadly, Bales et al. (2009, pgs. 39-40) describe human trafficking as "...the crime of carrying someone into slavery by force or by fraud". It is important to note that human trafficking does not require the transport of a person across international borders and the crime can be committed intrastate. Further, human trafficking is a crime regardless of whether or not the person goes willingly with the trafficker (Bales et al., 2009). The willingness or desire of an individual to migrate is critical in human smuggling, which can lead to human trafficking. Human smuggling differs from human trafficking in that smuggling requires the transport of a person across international borders and persons who wish to be smuggled typically pay the smuggler for the service. Nonetheless, smuggling can morph into human trafficking once the person has been relocated. If the relationship with the smuggler ends once the person reaches their destination this is considered human smuggling; however, if the smuggler entraps the person in the destination country and forces them into labor, prostitution, or other atrocities, this is considered human trafficking (Bales et al., 2009).

Cho (2015) states human trafficking research is still in its infancy; however, the body of literature exploring the root causes and drivers of human trafficking is growing. The literature has broadly categorized these factors as supply side, or 'push' factors, demand side or 'pull' factors and as facilitating factors. In regards to the push or supply factors, past research has found countries that suffer from poverty, crime, corruption, unstable institutions, and/or are plagued with conflict and upheaval tend to be the greatest source of human trafficking victims (Agbu, 2003; Bales, 2007; Cho, 2015; Rao \& Presenti, 2012; Surtees, 2008). These countries are often referred to as 'origin' countries as individuals seek to migrate out of these areas in search of a better life and in the process fall victim to human traffickers. In reference to pull or demand factors, wealth is primary determinant as wealthier countries tend to have a greater demand for low-skilled work and the means to pay the traffickers. Wealthier countries tend to be considered the 'destination' countries for most of the human trafficking victims (Cho, 2015). Finally, the presence of corruption and organized crime are facilitating factors as organized criminals tend to have established networks that often utilize corrupt officials. These established networks can assist traffickers in both the identification and relocation of victims.

\subsection{Income Inequality as a Push Factor}

Income inequality has also been emphasized in the literature as an important push or supply factor inspiring people to search for a better life. The theoretical argument is that when stark differences in income exist, the difference can not only make the poorest resentful of their circumstances, but also raise their expectations regarding better opportunities elsewhere (Cho, 2015; Jac-Kucharski, 2012; Mo, 2014). In other words, awareness that others have a considerably greater standard of living can be a motivating factor to migrate in search of a better life.

While past research has made strong arguments for the relevance of income distribution as a push factor, these results have not been established empirically. Specifically, using the UNODC (2006) measures of the outflow of human trafficking victims at the country level, Cho (2015) finds that economic inequality, as measured by the Gini index, does not have a significant impact on the outflow of human trafficking. Cho's (2015) results suggest that countries with greater income inequality, as measured by the Gini coefficient, are no more likely to be the source or originating country from which individuals seek to leave than countries with greater income equality. It is important to note that empirical studies often use the Gini coefficient developed by Corrado Gini in 1912, which measures the income distribution across countries as a measure of income inequality. Nonetheless, while the Gini coefficient is widely used and recognized as reliable measure of income inequality, it alone does not capture theoretical rationale for why differences in income levels encourage the poorer group to migrate in search of a better life.

Mo (2014) articulates this critical distinction by stating that it is not absolute poverty that is a root cause of trafficking, rather it is the perceived relative deprivation that explains the desire to seek a better life elsewhere and endure the associated risks of migration. In other words, it is the awareness that others are better off and that improved conditions do exist that drive self-betterment and risk-taking behaviors. Using a controlled survey conducted in trafficking-prone areas in Nepal, Mo (2014) finds that perceived relative deprivation, or the feeling that an individual's wealth is below a point of reference, increases the risks an individual will take to achieve positive economic outcomes. Mo (2014) offers 
empirical evidence at both the survey, micro-level and at a macro-level in Nepal that greater relative deprivation significantly increases trafficking incidences. It is important to note that the sense that one's wealth falls below a point of reference, or the perceived relative deprivation, is formed through comparisons of the lives of others. Pulling from social comparison theory, equity theory, and relative deprivation theory, Mo $(2014$, p. 5) states that, “...people do not simply evaluate the absolute value of their income, performance, achievements, etc., but that these evaluations are heavily influenced by comparisons with others." This suggests two crucial pieces in the relationship between income inequality and human trafficking outflows. First, differences in income must exist and, secondly, those differences must be known by the poor group such that relative comparisons can be made.

The first implication that differences in income must exist, reinforces the argument that income inequality in a country should be a determinant of human trafficking outflow. The second implication that the differences in incomes must be known by the poorest group, suggests that income inequality in and of itself is not sufficient to capture the motivation for the poorest to seek a better life elsewhere. The shortcoming of the Gini coefficient in this context is that it is a broad measure of income inequality that does not necessarily capture these two conditions. It is argued here that this is why income inequality, as measured by Gini, often fails to be significant in empirical analyses exploring the push factors of human trafficking. Inequality measures the dispersal of income in a society; however, a low level of inequality in a poor country suggests that everyone in the society earns a meager income. In this case, all citizens all earn approximately the same low wages and are not necessarily aware that others enjoy a higher incomes and an improved standard of living elsewhere. As Mo (2014) describes, if an individual's reference group is impoverished, the individual's 'aspirations window' is closed as their status is equal to their comparison group(s). Further, high levels of income inequality implies that a small number of individuals earn most of the country's income; however, this suggests two different scenarios for a wealthy versus a poor country in reference to society's overall well-being.

It is suggested here that the percentage of income attributed to the lowest ten percentile of the population will more effectively capture the 'aspirations window' as Mo (2014) describes. Using this measure will predict the effect on human trafficking outflows as the lowest ten percentile experiences marginal increases in income. It is argued that as the poorest become marginally better off, human trafficking outflows will increase for three reasons. First, as discussed above, individuals must be aware that others are relatively better off in order to develop a perception of relative deprivation. When the poorest experience marginal increases in income, there is an increased opportunity for this group to gain a greater awareness and knowledge about the world outside of their immediate, abject surroundings. Depending on living conditions, a marginal increase in income could raise an awareness or connection to the outside world through acquiring technology (radio, television, internet connection, etc.) or a means of travel other than by foot. Second, as the poorest become more connected and aware of world outside of their immediate surroundings, they are more likely to be preyed upon by human traffickers. Human traffickers employ a variety of deceptive ploys to trick potential victims into believing that there are opportunities for respectable work and a better life elsewhere. Several of these ploys require potential victims to have access to the internet as traffickers contact and lure their victims through social networking and internet advertisements (Dixon, 2013). Thus, with greater connectivity, victims can be targeted and shown images of appealing destinations and environments, when in reality they are being deceived of traffickers' true intent. Finally, as Black et al. (2006) discuss, as the poorest experience increases in wealth, migration increases as the cost to do so falls. Thus, an increase in income also enhances the ability for an individual to pay a smuggler to migrate. Recalling that human smuggling can morph into human trafficking once the destination location is reached, the ability to pay smugglers is yet another means for human trafficking outflows to increase.

In sum, it is argued that differences in population incomes do matter, but the Gini coefficient does not accurately capture the theoretical rationale for why differences in income, especially the income of the poorest in the population, should be a significant driver of human trafficking. It is hypothesized that the percentage of income in the poorest percentiles is a significant determinant of human trafficking outflows as it captures the theoretical underpinnings of the drivers of human trafficking. Thus, the hypothesis is stated:

H1: All else equal, as those in the lowest $10^{\text {th }}$ percentile in income become marginally better off, there will be an increase in human trafficking outflows.

\section{Data}

It is widely acknowledged that obtaining reliable, representative data on human trafficking is notoriously difficult (Aronowitz, 2009; Cho, 2015; Crane, 2013; Gajic-Veljanoski and Stewart, 2007; Mahmoud and Trebesch, 2009). Human trafficking is an underground, criminal activity, and as with most crimes, the criminals attempt to hide their activities. As a further complication, human trafficking victims are often unable to report the crime as they are typically physically constrained, face language barriers, and/or lack information about the crime and their legal rights. Thus, obtaining reliable data on human trafficking is remarkably difficult and any measure of human trafficking should be considered an estimate. 
The UNODC (2006) offers one of the only measures of human trafficking. Specifically, the UNODC provides an incident reporting index that grades countries on both the level of human trafficking outflow, or the degree to which a country can be considered a country of origin, and the level of inflow, or the degree to which a country can be considered a destination country. Countries are scored on a scale of one to five, where five indicates the highest degree of human trafficking in/outflows. To score the countries, the UNODC uses aggregated incidences codes in international reports and media over the period 1996 to 2003. Given the focus on the role of income inequality as a push factor to human trafficking, the UNODC (2006) human trafficking outflow by country is used to proxy the level of human trafficking supply, or the degree to which a country can be considered an origin country. The UNODC (2006) provides scaled, outflow data for 127 countries.

Data available through the World Bank is used to measure the percentage of income going to lowest ten percent of the population. Further, other control variables available through the World Bank are included in the regression models. Specifically, measures of GDP per capita, labor force participation rates, adolescent fertility rates, the proportion of urban population, and male and female unemployment rates were incorporated. Cho (2015) and others have used these control variables in empirical analyses exploring the drivers of human trafficking. Table 1, in Appendix A, provides the summary statistics for each of the variables included in the analysis.

\section{Empirical Model and Results}

As described above, the UNODC (2006) scores countries on a one to five scale. Countries with a score of one represent a 'Very Low' level of human trafficking outflow. A score of two represents a 'Low' level of human trafficking outflow, a score of three a 'Medium' level, a score of four a 'High' level, and a score of five represents a 'Very High' level of human trafficking outflow. Given the discrete and ordered nature of the outflow data, an ordered probit model is selected to test the above hypotheses. Model 1 is defined as:

$$
y_{i}^{*}=\mu_{i}+\beta \text { Lowest } 10+Z_{i}^{\prime} \gamma+\varepsilon_{i}
$$

Where $y^{*}$ is the UNODC's scaled incident reporting index for human trafficking origin countries (denoted by $i$ ), Lowest 10 is the percentage of income going to the lowest ten percent of the population, $Z$ ' is a vector of the control variables that are added step-wise, $\mu_{i}$ denotes the unobservable characteristics, and $\varepsilon_{i}$ is the error term that is considered to be uncorrelated with the regressors. As a robustness check, Model 2 replaces Lowest 10 with the Lowest20, the percentage of income going to the lowest 20 percent of the population, to test if this result holds beyond the extreme low end of the income spectrum. Model 2 is defined as:

$$
y_{i}^{*}=\mu_{i}+\beta_{i} \text { Lowest } 20+Z_{i}^{\prime} \gamma+\varepsilon_{i}
$$

\subsection{Analysis Results}

The analysis results, specifically the coefficient estimates, are presented in Tables 2 and 3 in Appendix B. As shown in Table 2, the results for Model 1 reveal a positive and significant coefficient on the Lowest 10 in all seven regressions, indicating that as the poorest ten percent become slightly better off, trafficking outflows increase. Further, as shown in Table 3, the results for Model 2 indicate a significant and positive coefficient on Lowest20 in six of the seven regressions. These results support $\mathrm{H} 1$.

\section{Conclusion}

Human trafficking is heinous crime that is growing at an alarming rate. As the president of the Economic and Social Council recently stated, a better understanding of the crime is needed in order to fight it. Developing this understanding is challenging as human trafficking is by its nature a complex crime that intertwines multiple push, pull, and facilitating factors and often involves other crimes such as illegal migration. Adding to the challenges is the difficulty of obtaining reliable and representative human trafficking data. Although Cho (2015) notes that human trafficking research is in its infancy, it is growing and researchers are identifying the multitude of factors that play a role in the crime.

In this vein, this study seeks to close the gap between the theoretical rationale for the role of income inequality in human trafficking and lack of empirical evidence supporting this relationship. It is argued that difference in income, especially the incomes of the poorest, do matter; however, it is not simply the dispersal of income in a society that serves as the driver. Specifically, significant differences in income must exist and the less fortunate group must be aware that such contrasts exists. It is the awareness that others are relatively better off that creates the perception of relative deprivation. It is this perception that can encourages individuals to partake in more risk-taking behaviors such as migration (Mo, 2014). Through a series of ordered probit regression models, empirical evidence is offered to support these claims.

The results presented here have relevant policy implications. In their efforts to fight human trafficking and educate potential victims, international organizations and aid workers should place a greater emphasis on areas in which there are contrasts in income, and especially those areas in which the poorest are becoming marginally better off. The 
empirical results indicate that as the poorest become marginally better off there is an increase in human trafficking outflow. It is hypothesized that as the poor make some economic gains, these gains could be used to acquire technology and/or means of travel that can connect them to the world outside of their immediate, impoverished surroundings. It is through these connections that an awareness of a better life elsewhere can be formed and these connections enhance the chance of being targeted and deceived by a trafficker. Further, marginal economic gains also increase the ability of these individuals to pay smugglers and, in the process of migration, become human trafficking victims.

While this study offers evidence to explain the discrepancy between the theoretical rationale for the role of income inequality in human trafficking and lack of empirical evidence, it should be noted that there are limitations to these findings. As noted, obtaining reliable, representative data on human trafficking is notoriously difficult. While the UNODC (2006) offers a measure of country-level human trafficking outflows that is based on aggregated incidences codes from international reports and media over (approximately) a seven year period of time, it must be acknowledged that any measure of human trafficking should be considered an estimate of a true, but unknown value. Given the clandestine nature of the crime, human trafficking is exceptionally difficult to quantify and the results presented here should be considered in this light.

\section{References}

Adepoju, A. (2005). Review of research and data on human trafficking in sub-Saharan Africa. International Migration, 43(1/2), 75 - 98. https://doi.org/10.1111/j.0020-7985.2005.00313.x

Agbu, O. (2003). Corruption and human trafficking: The Nigerian case. West Africa Review, 4(1), 1-13.

Aronowitz, Alexis A. (2009). Human Trafficking, Human Misery. Praeger Publishers, Westport, CT.

Bales, K. (2007). What predicts human trafficking? International Journal of Comparative and Applied Criminal Justice, 31(2), 269-279. https://doi.org/10.1080/01924036.2007.9678771

Bales, K., Trodd, Z., \& Williamson, A. K. (2009). Modern Slavery. Oneworld Publications, Oxford, England.

Black, R., Natalo, C., \& Skinner, J. (2006). Migration and inequality. Equity \& Development World Development Report.

http://siteresources.worldbank.org/INTWDR2006/Resources/477383-1118673432908/Migration_and_Inequality.p df

Cho, S-Y. (2015). Modeling for determinants of human trafficking: An empirical analysis. Social Inclusion, 3(1), 2-21. https://doi.org/10.17645/si.v3i1.125

Crane, A. (2013). Modern slavery as a management practice: Exploring the conditions and capabilities for human exploitation. Academy of Management Review, 38(1), 49-69. https://doi.org/10.5465/amr.2011.0145

Dijk, J. V., \& Mierlo, F. K-V. (2014). Quantitative indices for anti-human trafficking policies: based on reports of the U.S. Department and the Council of Europe. Crime, Law and Social Change, 61, 229-250. https://doi.org/10.1007/s10611-013-9510-6

Dixon, Herbert B. (2013). Human Trafficking and the Internet. The Judge's Journal, 52(1). https://www.americanbar.org/publications/judges_journal/2013/winter/human_trafficking_and_internet_and_other _technologies_too.html

Fitchtelberg, A. (2008). Crime without borders: An introduction to international criminal justice. Upper Saddle River, NJ: Pearson.

Gajic-Veljanoski, O. \& Stewart, D. E. (2007). Women trafficked into prostitution: Determinants, human rights and health needs. Transcultural Psychiatry, 44(3), 338-359. https://doi.org/10.1177/1363461507081635

Jac-Kucharski, A. (2012). The determinants of human trafficking: A US case study. International Migration, 50(6), 150-165. https://doi.org/10.1111/j.1468-2435.2012.00777.x

Mahmoud, T. O., \& Trebesch, C. (2009). The economic drivers of human trafficking: Micro-Evidence from five Eastern European countries. Kiel Working Paper No. 1480, February, 2009, http://www.econstor.eu/bitstream/10419/39939/1/38_trebesch.pdf

Mo, C. (2014). Perceived relative poverty and risk: An aspiration-based model of vulnerability. Standard University, Working Paper.

https://www.sas.upenn.edu/polisci/sites/www.sas.upenn.edu.polisci/files/Aspiration_Trafficking.pdf

Potrafke, N. (2013). Policies against human trafficking: The role of religion and political insitutions. CESifo Working Paper, No. 4278. 
Rao, S. \& Presenti, C. (2012). Understanding human trafficking origin: A cross-country empirical analysis. Feminist Economics, 18(2), 231-263. https://doi.org/10.1080/13545701.2012.680978

Sigmon, J. N. (2008). Combating modern-day slavery: Issues in identifying and assisting victims of human trafficking worldwide. Victims \& Offenders, 3(2-3), 245-257. https://doi.org/10.1080/15564880801938508

Studnicka, A. C. S. (2010). Corruption and human trafficking in Brazil: Findings from a multi-modal approach. European Journal of Criminology, 7(1), 29-43. https://doi.org/10.1177/1477370809347925

Surtees, R. (2008). Traffickers and trafficking in Southern and Eastern Europe. European Criminology, 5(1), 3968. https://doi.org/10.1177/1477370807084224

United Nations Office on Drugs and Crime. (n.d.). Human trafficking FAQs. http://www.unodc.org/unodc/en/human-trafficking/faqs.html

United Nations Office on Drugs and Crime (UNODC). (2006). Global Report on Trafficking in Persons. Vienna: UN.

United Nations. (2000). Protocol to Prevent, Suppress and Punish Trafficking in Persons, especially Women and Children. http://www.ohchr.org/EN/ProfessionalInterest/Pages/ProtocolTraffickingInPersons.aspx

Wheaton, E. M., Schauer, E. J., \& Galli, T. V. (2010). Economics of human trafficking. International Migration, 48(4), 114-141. https://doi.org/10.1111/j.1468-2435.2009.00592.x

Winterdyk, J. \& Reichel, P. (2010). Introduction to special issue human trafficking: Issues and perspectives. European Journal of Criminology, 7(1), 5-10. https://doi.org/10.1177/1477370809347894

\section{Appendix A}

\section{Descriptive Statistics}

Table 1. Descriptive statistics

\begin{tabular}{|c|c|c|c|c|c|c|}
\hline Description & $\begin{array}{l}\text { Variable } \\
\text { Name }\end{array}$ & Obs & Mean & Std. Dev & Minimum & Maximum \\
\hline UNODC Outflow Index & unodc_orig & 105 & 3.095238 & 1.087727 & 1 & 5 \\
\hline $\begin{array}{l}\text { Percentage of Income going to Lowest } 10 \\
\text { percent }\end{array}$ & lowest10 & 105 & 2.472381 & .8957695 & .5 & 4.4 \\
\hline $\begin{array}{l}\text { Percentage of Income going to Lowest } 20 \\
\text { percent }\end{array}$ & lowest 20 & 105 & 6.280952 & 1.897929 & 2 & 10.3 \\
\hline Real GDP per Capita & GDPPC & 105 & 4561.804 & 7648.381 & 197.0667 & 44892.78 \\
\hline Labor Force Participation Rate & LF Part & 105 & 65.20299 & 10.00523 & 44.42857 & 88.95714 \\
\hline Adolescent Fertility Rate & AF Rate & 105 & 76.55622 & 51.98774 & 6.638743 & 218.8607 \\
\hline $\begin{array}{l}\text { Proportion of Population living in Urban } \\
\text { Areas }\end{array}$ & P Urban & 105 & 47.25441 & 20.36127 & 8.254429 & 92.00971 \\
\hline Male Unemployment Rate & Male U & 105 & 8.921224 & 5.934939 & .8142857 & 32.64286 \\
\hline Female Unemployment Rate & Fem U & 105 & 11.10884 & 7.758583 & .4 & 40.75714 \\
\hline
\end{tabular}




\section{Appendix B}

\section{Estimated Regression Results}

Table 2. Model 1 estimated ordered probit results

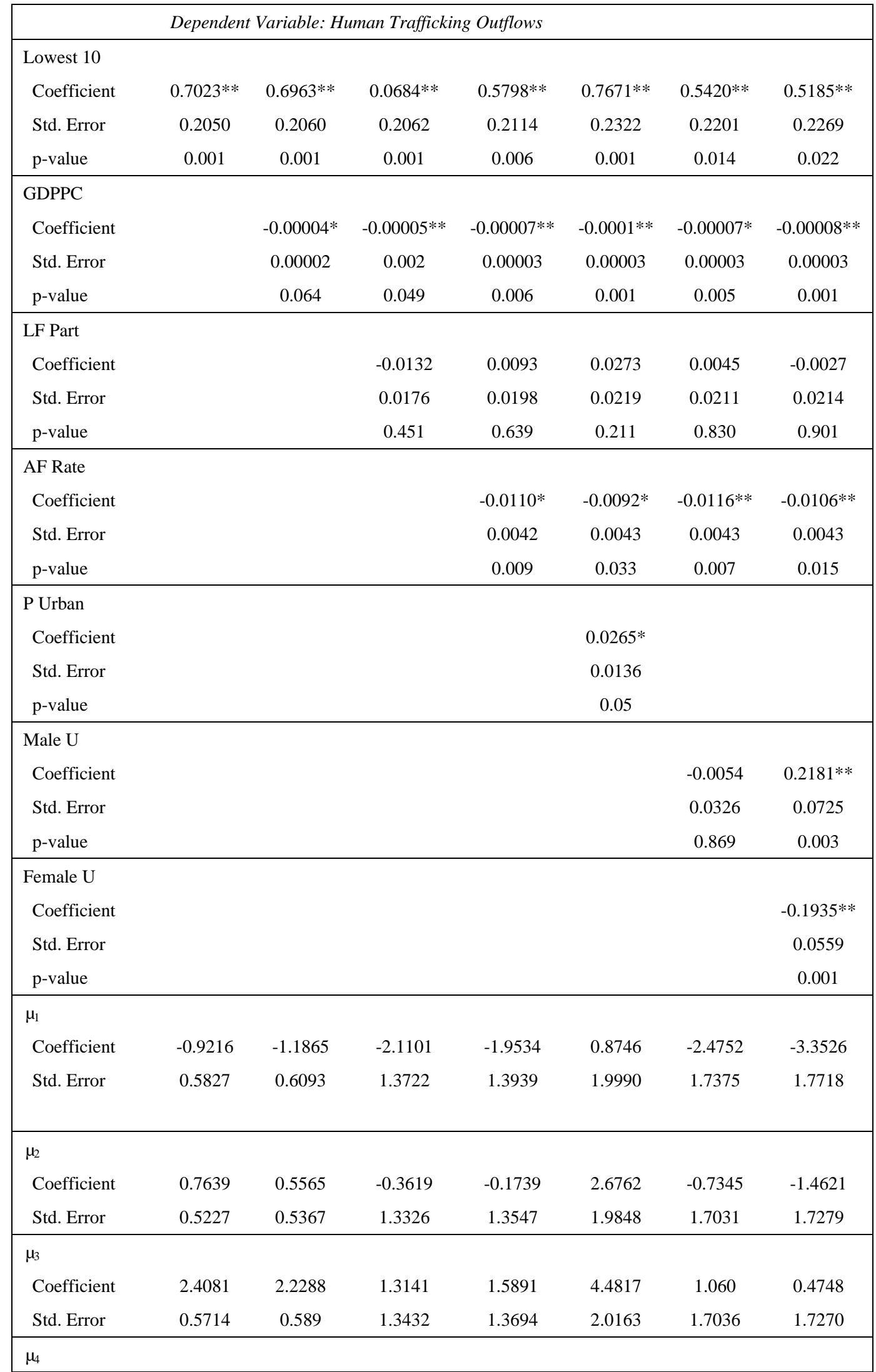




\begin{tabular}{|lccccccc|}
\hline Coefficient & 4.0513 & 3.8751 & 2.9650 & 3.3243 & 6.2816 & 2.8022 & 2.3207 \\
Std. Error & 0.6608 & 0.6692 & 1.3762 & 1.4111 & 2.0742 & 1.7329 & 1.7531 \\
\hline Likelihood Ratio & 12.29 & 15.53 & 16.10 & 23.16 & 27.02 & 23.57 & 36.12 \\
p-value & 0.0005 & 0.0004 & 0.0011 & 0.0001 & 0.0001 & 0.003 & 0.000 \\
Pseudo $R^{2}$ & 0.0393 & 0.0497 & 0.0515 & 0.0741 & 0.0865 & 0.0762 & 0.1162 \\
$n$ & 106 & 106 & 106 & 106 & 106 & 105 & 105 \\
\hline
\end{tabular}

$* * *$ Significant at $99 \% \quad * *$ Significant at $95 \% \quad *$ Significant at $90 \%$

Table 3. Model 2 estimated ordered probit results

\begin{tabular}{|c|c|c|c|c|c|c|c|}
\hline \multirow[b]{2}{*}{ Lowest 20} & \multicolumn{6}{|c|}{ Dependent Variable: Human Trafficking Outflows } & \multirow[b]{3}{*}{$0.2798 * *$} \\
\hline & & & & & & & \\
\hline Coefficient & $0.3527 * * *$ & $0.36644 * * *$ & $0.3576^{* * *}$ & $0.3106^{* *}$ & $0.3932 * * *$ & $0.2969 * *$ & \\
\hline Std. Error & 0.0975 & 0.9821 & 0.0986 & 0.10067 & 0.1095 & 0.1046 & 0.1077 \\
\hline p-value & 0.000 & 0.000 & 0.000 & 0.002 & 0.000 & 0.005 & 0.009 \\
\hline \multicolumn{8}{|l|}{ GDPPC } \\
\hline Coefficient & & $-0.00005 * *$ & $-0.00005^{* *}$ & $-0.0007 * *$ & $-0.0001 * *$ & $-0.00008 * *$ & $-0.0009 * *$ \\
\hline Std. Error & & 0.00002 & 0.00002 & 0.0003 & 0.00003 & 0.00003 & 0.00003 \\
\hline p-value & & 0.003 & 0.027 & 0.004 & 0.001 & 0.003 & 0.001 \\
\hline \multicolumn{8}{|l|}{ LF Part } \\
\hline Coefficient & & & -0.0109 & 0.0110 & 0.0260 & 0.0067 & -0.0004 \\
\hline Std. Error & & & 0.0177 & 0.0198 & 0.0220 & 0.0212 & 0.0214 \\
\hline p-value & & & 0.538 & 0.580 & 0.178 & 0.750 & 0.984 \\
\hline \multicolumn{8}{|l|}{ AF Rate } \\
\hline Coefficient & & & & $-0.0108 * *$ & $-0.0091 * *$ & $-0.0113 * *$ & $-0.0104 * *$ \\
\hline Std. Error & & & & 0.0042 & 0.0043 & 0.0043 & 0.0043 \\
\hline p-value & & & & 0.010 & 0.035 & 0.008 & 0.016 \\
\hline \multicolumn{8}{|l|}{ P Urban } \\
\hline Coefficient & & & & & $0.0265^{* *}$ & & \\
\hline Std. Error & & & & & 0.0134 & & \\
\hline $\mathrm{p}$-value & & & & & 0.048 & & \\
\hline \multicolumn{8}{|l|}{ Male U } \\
\hline Coefficient & & & & & & -0.0025 & $0.2161 * *$ \\
\hline Std. Error & & & & & & 0.03248 & 0.0722 \\
\hline $\mathrm{p}$-value & & & & & & 0.938 & 0.003 \\
\hline
\end{tabular}




\begin{tabular}{|c|c|c|c|c|c|c|c|}
\hline Coefficient & & & & & & & $-0.1899 * *$ \\
\hline Std. Error & & & & & & & 0.0559 \\
\hline p-value & & & & & & & 0.001 \\
\hline \multicolumn{8}{|l|}{$\mu_{1}$} \\
\hline Coefficient & -0.4645 & -0.68890 & -1.4646 & -1.3629 & 1.5417 & -1.8081 & -2.7384 \\
\hline Std. Error & 0.6635 & 0.6806 & 1.4320 & 1.4518 & 2.0591 & 1.7975 & 1.8344 \\
\hline \multicolumn{8}{|l|}{$\mu_{2}$} \\
\hline Coefficient & 1.2292 & 1.0739 & 0.30228 & 0.4322 & 3.3618 & -0.0526 & -0.8338 \\
\hline Std. Error & 0.6176 & 0.6237 & 1.3977 & 1.4177 & 2.0492 & 1.7673 & 1.7952 \\
\hline \multicolumn{8}{|l|}{$\mu_{3}$} \\
\hline Coefficient & 2.8915 & 2.7766 & 2.0069 & 22216 & 5.1934 & 1.7679 & 1.1254 \\
\hline Std. Error & 0.6720 & 0.6767 & 1.4166 & 1.4401 & 2.0855 & 1.7754 & 1.8023 \\
\hline \multicolumn{8}{|l|}{$\mu_{4}$} \\
\hline Coefficient & 4.5479 & 4.4416 & 3.6753 & 3.9757 & 7.0128 & 3.530 & 2.9893 \\
\hline Std. Error & 0.7579 & 0.7626 & 1.4532 & 1.4854 & 2.1460 & 1.809 & 1.8327 \\
\hline Likelihood Ratio & 13.77 & 18.09 & 18.47 & 25.28 & 29.24 & 25.58 & 37.72 \\
\hline$p$-value & 0.0002 & 0.0001 & 0.0004 & 0.0000 & 0.0000 & 0.0001 & 0.0000 \\
\hline Pseudo $R^{2}$ & 0.0440 & 0.0579 & 0.0591 & 0.0809 & 0.0936 & 0.0830 & 0.1219 \\
\hline$n$ & 106 & 106 & 106 & 106 & 106 & 105 & 105 \\
\hline
\end{tabular}

\section{Copyrights}

Copyright for this article is retained by the author(s), with first publication rights granted to the journal.

This is an open-access article distributed under the terms and conditions of the Creative Commons Attribution license (http://creativecommons.org/licenses/by/4.0/). 